\title{
KARAKTERISTIK KASUS KEKERASAN SEKSUAL PADA PEREMPUAN DI BLUD RUMAH SAKIT CUT MEUTIA BERDASARKAN VISUM ET REPERTUM PERIODE TAHUN 2018
}

\author{
Iskandar Albin ${ }^{1}$, Zubir $^{2}$ \\ ${ }^{1}$ Bagian Ilmu Obstetri dan Ginekologi Fakultas Kedokteran Universitas Malikussaleh \\ ${ }^{2}$ Bagian MEU Fakultas Kedokteran Universitas Malikussaleh \\ Corresponding Author: i.albin@yahoo.com
}

\begin{abstract}
Abstrak
Kekerasan atau violence diartikan sebagai suatu serangan atau invasi (assault) terhadap fisik maupun integritas mental psikologis seseorang. Bentuk kekerasan terhadap perempuan meliputi kekerasan fisik, seksual, ekonomi, secara politik, dan psikologis. Kekerasan Seksual adalah setiap perbuatan merendahkan, menghina, menyerang, dan/atau perbuatan lainnya terhadap tubuh, hasrat seksual seseorang, dan/atau fungsi reproduksi, secara paksa, bertentangan dengan kemauan seseorang. Prevalensi kekerasan seksual terhadap wanita masih sangat tinggi. Tujuan penelitian ini untuk mengetahui karakteristik kasus kekerasan seksual pada perempuan di BLUD Rumah Sakit Cut Meutia berdasarkan Visum et Repertum periode tahun 2018. Data didiambil dari hasil Visum et Repertum yang dibuat di RSU Cut Meutia dari bulan Januari 2018- Desember 2018 berjumlah 46 orang. Penelitian ini merupakan penelitian deskriptif dengan pendekatan Cross Sectional. Variabel yang dinilai dalam penelitian ini adalah umur, lokasi pelaporan kejadian kekerasan seksual, jenis kekerasan seksual, kekerasan fisik yang terjadi pada korban, dan kekerasan verbal yang terjadi pada Dari hasil penelitian didapatkan kejadian kekerasan seksual berdasarkan usia paling banyak berada pada kelompok usia 5-14 tahun sebanyak 24 orang $(52,2 \%)$ dengan tempat pelaporan paling banyak berasal dari Resor Lhokseumawe sebanyak 28 orang $(60,9 \%)$. Jenis kekerasan seksual yang paling banyak berada pada kelompok kontak tipe penetrasi sebanyak 30 orang $(65,2 \%)$ dan hubungan korban dengan pelaku kekerasan seksual paling banyak berada pada kelompok yang berasal dari orang yang tidak dikenal sebanyak 14 orang (30,4\%). Pada korban kekerasan seksual sebanyak 11 orang $(23,9 \%)$ juga mengalami kekerasan fisik dan sebanyak 18 orang $(39,1 \%)$ mengalami kekerasan verbal.
\end{abstract}

Kata kunci : kekerasan seksual; perempuan; visum et repertum 


\title{
Charasteristics of Sexual Violence on Women in Cut Meutia General Hospital Based on Visum et Repertum Period of 2018
}

\begin{abstract}
Violence is defined as an attack or assault on a person's physical and psychological mental integrity. Types of violence against women include physical, sexual, economic, political, and psychological violence. Sexual Violence is defined as any act of condescending, insulting, attacking, and / or other acts against the body, a person's sexual desires, and / or reproductive functions, by force, contradictory to the person's will. The prevalence of sexual violence against women is still very high. The purpose of this study was to determine the characteristics of sexual violence cases against women in Cut Meutia General Hospital based on visum et repertum in 2018. Data was drawn from visum et repertum made in Cut Meutia General Hospital from January to December of 2018, covering total of 46 cases. This is a descriptive research with a cross sectional approach. The variables assessed in this study were age, location of sexual violence incidence report, types of sexual violence, victim-perpetrator relation, physical violence occurence, and verbal violence occurence. The results of the study show that the incidence of sexual violence was highest in age group of 5-14 years with 24 people (52.2\%), reporting location was highest from Lhokseumawe Resort with 28 people $(60.9 \%)$, type of sexual violence was highest in the penetrative contact group with 30 people $(65.2 \%)$, victim-perpetrator relation was highest in no relation group with 14 people $(30.4 \%)$. A number of 11 people (23.9\%) and 18 people (39.1\%) also experienced physical and verbal violence, respectively.
\end{abstract}

Keywords: sexual violence, women, visum et repertum

\section{PENDAHULUAN}

Kekerasan atau violence diartikan sebagai suatu serangan atau invasi (assault) terhadap fisik maupun integritas mental psikologis seseorang. ${ }^{3}$ Bentuk kekerasan terhadap perempuan meliputi kekerasan fisik, seksual, ekonomi, secara politik, dan psikologis yang dapat dilakukan baik oleh individu, komunitas, maupun negara. ${ }^{2}$ Kekerasan Seksual adalah setiap perbuatan merendahkan, menghina, menyerang, dan/atau perbuatan lainnya terhadap tubuh, hasrat seksual seseorang, dan/atau fungsi reproduksi, secara paksa, bertentangan. ${ }^{1}$ Jenis kekerasan seksual yang dapat terjadi yaitu kejahatan kekerasan seksual (sexual violence) dan pelecehan seksual (sexual harrassment). ${ }^{3}$

Kekerasan/pelecehan seksual adalah setiap penyerangan yang bersifat seksual terhadap perempuan, baik telah terjadi persetubuhan ataupun tidak, dan tanpa mempedulikan hubungan antara pelaku dan korban. Kekerasan/pelecehan seksual dapat sangat bervariasi berupa percobaan perkosaan, perkosaan, sadisme dalam hubungan seksual, pemaksaan aktivitas-aktivitas seksual lain yang tidak disukai, merendahkan, menyakiti atau melukai korban. ${ }^{3}$ Kekerasan terhadap perempuan memiliki ciri penting bahwa tindakan tersebut dapat berupa tindakan fisik, seksual, maupun nonfisik (psikis), dapat dilakukan secara aktif maupun 
pasif (tidak berbuat), dikehendaki atau diniati oleh pelaku, dan menimbulkan akibat yang merugikan korban (fisik, seksual, maupun psikis) yang tidak dikehendaki oleh korban. ${ }^{2}$

Prevalensi kekerasan seksual terhadap wanita masih sangat tinggi. Di dunia, rerata sebanyak 35,6\% atau 1 dari 3 orang wanita pernah mengalami kekerasan seksual baik oleh pasangan, bukan pasangan, atau keduanya. Tingginya angka tersebut menandakan masih lumrahnya kekerasan seksual di kehidupan banyak wanita. Kekerasan seksual di negaranegara berkembang (low/medium income countries) cenderung lebih tinggi dibandingkan negara maju (high income countries). Prevalensi kekerasan seksual tertinggi berada di negaranegara Afrika (45,6\%) dan Asia Tenggara (40,2\%). ${ }^{1}$ Indonesia sendiri tidak luput dari hal ini yang dapat dilihat dari tren kekerasan pada wanita yang terus meningkat dari tahun ke tahun. ${ }^{2}$

Kekerasan seksual dapat menyebabkan berbagai permasalahan kesehatan bagi korban, seperti cedera atau trauma fisik, kehamilan yang tidak direncanakan, induced abortion, masalah-masalah ginekologis, dan infeksi menular seksual (IMS), termasuk HIV. Jika kekerasan seksual dilakukan pada wanita yang sedang hamil dapat meningkatkan kemungkinan abortus, janin lahir mati, kelahiran preterm, dan berat bayi lahir rendah (BBLR). Selain itu kekerasan ini juga dapat berujung pada gangguan psikis seperti depresi, post-traumatic stress disorder (PTSD) dan gangguan kecemasan lain, gangguan tidur, gangguan makan, dan percobaan bunuh diri. $^{3}$

Berdasarkan tingginya prevalensi kekerasan seksual pada wanita dan dampaknya terhadap kesehatan korban maka peneliti tertarik melakukan penelitian tentang kasus kekerasan seksual pada perempuan.

\section{METODE PENELITIAN}

\section{Desain Penelitian}

Penelitian ini menggunakan metode deskriptif dengan pendekatan cross sectional.

\section{Populasi dan Sampel Penelitian}

Populasi dalam penelitian ini adalah seluruh kasus kekerasan seksual yang dilaporkan dan dibuatkan surat keterangan (visum et repertum) di BLUD RS Cut Meutia Aceh Utara tahun 2016-2018 dan sampel dalam penelitian ini adalah seluruh kasus kekerasan seksual yang dilaporkan dan dibuatkan surat keterangan (visum et repertum) di BLUD RS Cut Meutia Aceh Utara tahun 2016-2018. 


\section{Teknik Pengambilan Sampel}

Teknik pengambilan sampel dalam penelitian ini menggunakan metode total sampling.

\section{Instrumen Penelitian}

Instrumen yang digunakan dalam penelitian ini adalah visum et repertum yang diambil di Rekam Medih BLUD Rumah sakit Cut Meutia Aceh Utara.

\section{Analisis Data}

Analisis dan penyajian data yang dilakukan adalah analisis univariat variabel kekerasan seksual menggunakan software statistika.

\section{HASIL PENELITIAN}

Penelitian ini didapatkan hasil yang dapat dilihat dalam tabel berikut :

\section{Tabel 1 Karakteristik Responden}

\begin{tabular}{lcc}
\hline \multicolumn{1}{c}{ Karakteristik } & $\mathrm{N}$ & $\%$ \\
\hline Usia & 3 & \\
1-4 tahun & 24 & 6,5 \\
5-14 tahun & 15 & 52,2 \\
15-24 tahun & 4 & 32,6 \\
25-41 tahun & 18 & 8,7 \\
Wilayah & 28 & 39,1 \\
$\quad$ Resor Aceh Utara & & 60,9 \\
$\quad$ Resor Lhokseumawe & 30 & 65,2 \\
Tipe kekerasan Seksual & 10 & 21,7 \\
$\quad$ Penetrasi & 6 & 13,0 \\
$\quad$ Kontak & & \\
$\quad$ Non kontak & 11 & 23,9 \\
Kekerasan Fisik & 35 & 76,1 \\
$\quad$ Ya & & \\
Tidak & 18 & 39,1 \\
Kekerasan Verbal & 28 & 60,9 \\
$\quad$ Ya & & \\
$\quad$ Tidak & 6 & 13,0 \\
Hubungan Pelaku dan Korban & 10 & 21,7 \\
Keluarga & 6 & 21,0 \\
Tetangga & 10 & 30,4 \\
$\quad$ Kenalan & 14 & \\
Teman & &
\end{tabular}

(Sumber: Data Primer, 2018) 
Tabel 1 menunjukkan karakteristik responden berdasarkan usia, wilayah, tipe kekerasan seksual, kekerasan fisik, kekerasan verbal, dan hubungan pelaku dan korban pada sampel yang berjumlah 46 orang di PPK BLUD RSU Daerah Cut Meutia sepanjang tahun 2018. Berdasarkan kelompok usia, kelompok terbanyak berada pada usia 5-14 tahun sebanyak 24 orang $(52,2 \%)$ dan paling sedikit pada kelompok usia 1-4 tahun sebanyak 3 orang $(6,5 \%)$.

Bedasarkan wilayah pelaporan terjadinya kekerasan seksual, lokasi terbanyak berasal dari Resor Lhokseumawe sebanyak 28 orang (60,9\%), dan paling sedikit berasal dari Resor Aceh Utara sebanyak 18 orang (39,1\%). Berdasarkan hubungan pelaku dan korban, kejadian terbanyak kekerasan seksual dilakukan oleh pelaku yang berasal dari orang yang tidak dikenal sebanyak 14 orang $(30,4 \%)$ dan paling sedikit dilakukan oleh pelaku yang berasal dari keluarga dan kenalan sebanyak masing masing 6 orang $(13,0 \%)$.

Berdasarkan tipe kekerasan seksual yang terjadi, kasus terbanyakyaitukekerasan seksual tipe penetrasi sebanyak 30 orang $(65,2 \%)$ dan yang paling sedikit yaitu tipe kekerasan seksual non kontak sebanyak 6 orang $(13,0 \%)$. Berdasarkan jenis kekerasan yang terjadi sebanyak 11 orang dari 46 orang $(23,9 \%)$ mengalami kekerasan seksual dan kekerasan fisik, dan kekerasan verbal juga terjadi pada 18 orang dari 46 orang $(39,1 \%)$.

\section{PEMBAHASAN}

\section{Umur}

Pada penelitian ini didapatkan bahwa korban kekerasan seksual pada perempuan terbanyak terdapat pada kelompok umur 5-14 tahun yaitu sebanyak 24 orang (52,2\%), diikuti 15-24 tahun sebanyak 15 orang (32,6\%), 25-41 tahun sebanyak 4 orang $(8,7 \%)$, dan paling sedikit pada 1-4 tahun sebanyak 3 orang (6,5\%). Hasil ini secara garis besar sejalan dengan penelitian yang dilakukan oleh Indrayana (2017). Pada penelitiannya pada salah satu rumah sakit di Dumai terhadap 120 korban kekerasan seksual, 119 diantaranya merupakan perempuan. Dari 119 itu, sebanyak 114 orang (95,8\%) merupakan perempuan berusia 0-18 tahun. Disusul 4 orang $(3,4 \%)$ dari kelompok 19-24 tahun dan 1 orang $(0,8 \%)$ dari kelompok 25-44 tahun. ${ }^{15}$

Hasil ini juga sejalan dengan Catahu Komnas Perempuan (2019) yang mendapatkan bahwa mayoritas korban kekerasan seksual di ranah komunitas tergolong dalam umur 13-18 tahun, diikuti oleh 25-40 tahun, 19-24 tahun, 6-12 tahun, $>40$ tahun, dan $<5$ tahun. ${ }^{5}$ 


\section{Tipe Kekerasan Seksual}

Jenis kekerasan seksual yang dialami korban pada penelitian ini sebagian besar adalah mengalami penetrasi yaitu 30 kasus $(65,2 \%)$, diketahui bahwa perilaku menyimpang pada saat dewasa pada lelaki dan perempuan sering kali disebabkan oleh karena adanya kekerasan seksual yang melibatkan penetrasi. Penelitian Negri $\mathrm{dkk}^{16}$ pada tahun 2014 mendapatkan jenis kekerasan seksual yang paling banyak adalah kekerasan dengan kontak tanpa penetrasi yaitu sebanyak 45\%, sedangkan kekerasan seksual dengan penetrasi hanya 38,3\%. Hasil serupa didapatkan oleh Bourke $\mathrm{dkk}^{17}$, kekerasan seksual dengan penetrasi organ intim pada pelaku lelaki hanya tercatat sebesar $17 \%$. Kekerasan seksual dengan atau tanpa penetrasi memberikan dampak yang sama terhadap psikologi dari korban kekerasan seksual. Keadaan ini dapat terjadi karena kurangnya kesadaran masyarakat akan kekerasan seksual ataupun sebagian besar masyarakat tidak melaporkan kekerasan seksual tersebut karena stigma dalam masyarakat, kecuali untuk kasus yang berat (terjadi penetrasi).

Hymen yaitu lapisan selaput yang sangat tipis dan merentang di bagian bawah vagina wanita yang umumnya berbentuk seperti cincin dengan lubang kecil untuk keluarnya darah menstruasi. Perubahan bentuk hymen dapat terjadi seiring bertambahnya usia, khususnya pada usia remaja atau memasuki masa pubertas. Hymen cenderung lebih elastis pada usia remaja dan akan menebal pada saat dewasa akibat perubahan hormon seperti hormon estrogen. Hymen ini dapat dilihat menggunakan cermin dengan merentangkan bibir vagina. Dalam masyarakat umum, atribut perempuan sebagai seorang perawan diidentifikasi melalui utuh-tidaknya selaput dara tersebut. Sebagian besar masyarakat percaya bahwa perempuan yang sudah tidak memiliki hymen (robek) pernah melakukan hubungan seksual. Pemikiran seperti ini biasanya mengakibatkan adanya praktik kekerasan dalam rumah tangga dari suami yang menemukan bahwa istrinya sudah tidak perawan lagi akibat tidak adanya selaput dara yang robek pada hubungan seksual mereka yang pertama. Padahal, selaput dara tidak hanya robek hanya karena peristiwa penetrasi penis ke dalam vagina saat berhubungan seksual. hymen juga dapat robek saat menjalankan aktivitas berat seperti berkuda hingga masturbasi yang menggunakan alat bantu seks, sehingga utuh-tidaknya selaput dara seharusnya tidak dapat menjadi patokan keperawanan secara umum. Dalam beberapa tindakan medis tertentu pun sangat memungkinkan perobekan selaput dara terjadi. Selaput dara yang robek akibat trauma fisik maupun cedera pada masa anak-anak dan remaja masih dapat pulih dengan cepat ketika usia masih belum dewasa.

Korban yang masih berusia anak-anak sering tidak menceritakan kekerasan yang dialaminya oleh karena anak belum mengetahui nilai sosial, atau anak dalam ancaman sik 
dan/atau verbal oleh pelaku untuk merahasiakannya. Para orang tua korban sering menarik kembali keingi- nan untuk melapor oleh karena rasa malu apabila kejadian kekerasan seksual yang dialami anak bukan kasus yang berat.

\section{Wilayah Kekerasan Seksual}

Berdasarkan penelitian Bahri dan Fajriani ${ }^{18}$, kasus pelecehan seksual yang terjadi di Provinsi Aceh dewasa ini, banyak dialami anak- anak dan remaja, khususnya perempuan. Secara umum, korban pelecehan seksual adalah anak-anak dan remaja yang berusia di bawah 18 tahun, hanya dalam beberapa kasus pelecehan seksual saja yang korbannya merupakan perempuan dewasa. Hal ini disebabkan pada usia anak-anak dan remaja, mereka belum memahami dengan baik tentang pendidikan seks dan pelecehan seksual, tentang perilaku mana yang harus dihindari, serta tentang akibat yang akan timbul dari tindakan asusila tersebut. Di samping itu, anak-anak dan remaja cenderung tidak punya kekuatan untuk menolak keinginan si pelaku, ditambah lagi pelaku mengancam korban secara sik dan psikis. Berbeda halnya dengan pelaku pelecehan seksual. Profil pelaku pelecehan seksual berbeda, baik itu dari latar belakang pendidikan, pekerjaan, tempat tinggal, maupun status sosial ekonomi. Namun yang menjadikannya sama adalah semua pelaku pelecehan seksual yang ditemui adalah laki-laki.

Data yang diperoleh dari rekam medik Rumah Sakit Umum Cut Meutia diketahui bahwa angka pelecehan seksual yang terjadi pada dua resor berjumlah 46 kasus yaitu resor Aceh Utara berjumlah 18 kasus dan Resor Lhokseumawe berjumlah 28 kasus. Angka ini hanya berdasarkan laporan yang masuk ke kedua resor yang ditindak lanjuti untuk dibuat visum et repertum oleh pihak rumah sakit. Pelecehan yang tidak dilaporkan dapat disebabkan oleh karena masyarakat belum mengetahui perilaku pelecehan beserta hukuman terhadap pelakunya.

Berdasarkan data yang diperoleh dari Polres Aceh Utara bahwa jumlah kasus pelecehan seksual yang terjadi selama tiga tahun terakhir mengalami penurunan. Pada tahun 2012 terjadi 15 kasus, tahun 2013 menjadi 14 kasus, dan hingga bulan September 2014 menjadi 8 kasus pelecehan seksual berupa pencabulan dan pemerkosaan. Adapun besarnya penurunan jumlah kasus dalam tiga tahun terakhir namun data tahun 2018 menunjukkan adannya peningkatan pelecehan seksual menjadi 18 kasus. ${ }^{19}$ 


\section{Hubungan Pelaku dan Korban}

Hasil penelitian menunjukkan bahwa kelompok hubungan tertinggi yaitu orang tidak dikenal, dalam artian pelaku merupakan orang asing bagi korban, sebanyak 14 orang (30,4\%), diikuti oleh teman dan tetangga yang masing-masing 10 orang $(21,7 \%)$, dan terakhir dari keluarga dan kenalan, masing-masing 6 orang (13,0\%). Sekalipun demikian, dapat disimpulkan bahwa sebagian besar pelaku merupakan orang yang dikenal korban (keluarga, tetangga, kenalan, maupun teman) yaitu sebanyak 32 orang $(69,6 \%)$.

Hal ini sejalan dengan penilitian Herlianto et al. (2019) di Bali yang menunjukkan bahwa dari 88 kasus kekerasan seksual, 74 kasus (84\%) diantaranya dilakukan oleh orang yang dikenal, sedangkan sisanya yaitu 14 kasus (16\%) dilakukan oleh orang yang tidak dikenal. $^{20}$

Demikian pula dengan hasil penelitian Biruny et al. (2015). Dari 16 kasus yang dianalisis dalam penelitian mereka, 15 kasus (93,8\%) menunjukkan bahwa pelaku merupakan orang yang dikenal korban seperti keluarga, tetangga, terapis, guru, kerabat, kekasih, dan kenalan lain. Hanya 1 kasus $(6,2 \%)$ yang dilakukan oleh orang tidak dikenal/asing, dalam kasus ini merupakan seorang perampok. ${ }^{21}$

Hal ini dapat terjadi oleh karena terdapat ikatan emosional dan kesesuaian pada korbandengan pelaku yang merupakan salah satu faktor terjadinya kekerasan seksual. Tiga faktor lainnya yang ketika digabungkan akan memicu perbuatan kekerasan seksual pada anak: gairah seksual pada anak, "hambatan" pada hubungan seksual yang normal, dan kurangnya pengendalian diri dalam menahan impulsivitas. ${ }^{20}$

\section{Kejadian Kekerasan Fisik dan Verbal pada Korban Kekerasan Seksual}

Pada korban yang mengalami kekerasan seksual akan memiliki kecenderungan untuk mengalami kekerasan yang lainnya. Pada penelitian sebelumnya dilaporkan bahwa korban kekerasan seksual kemungkinan untuk terpapar kekerasan fisik, psikologis, dan penelantaran lebih tinggi, dibandingkan korban yang belum pernah mengalami kekerasan seksual. ${ }^{20}$ Pada penelitian ini didapatkan bahwa 23,9\% dari korban mengalami kekerasan fisik dan 39,1\% dari korban mengalami kekerasan verbal. Hasil ini sejalan dengan penelitian Agumasie Semahegn (2015) bahwa prevalensi kekerasan fisik terjadi pada wanita dengan kekerasan seksual berkisar antara 31-76,5\%. Kekerasan fisik terutama dalam keluarga banyak terjadi terkait dengan konsumsi alkohol, riwayat kekerasan dalam keluarga, pekerjaan, agama, tempat tinggal, dan kekuatan dalam pengambilan keputusan. 
Kekerasan fisik yang terjadi pada wanita dengan kekerasan seksual paling banyak dilakukan oleh suami atau keluarga terhadap wanita berkisar antara 31 hingga 76,5\% (Semahegn \& Mengistie, 2015). Dari prevalensi tersebut, sekitar tiga perempat mengalami pemukulan berulang-ulang seperti dipukul oleh tongkat, ditampar, ditengang, pada bagian tubuh yang berbeda, dipukul, ditusuk, dan berbagai mekanisme pelecehan lainnya. Berdasarkan studi berbasis komunitas cross sectional lain di Tigray dan zona Wollo Selatan menunjukkan bahwa prevalensi kekerasan seksual seumur hidup dilakukan oleh pasangan intim adalah 32,3\% [95\% CI: 28,7-35,9\%]. Namun, mayoritas perempuan akan tetap diam tanpa melaporkan kekerasan kepada badan instansi terkait. ${ }^{22}$

Prevalensi kejadian wanita dengan kekerasan seksual yang mengalami kekerasan emosional dan verbal sekitar 51,7\% (Semahegn \& Mengistie, 2015). Lebih dari sepertiga $(35,7 \%)$ wanita melaporkan mendapat ancaman pemukulan, diancam akan direndam, mengalami degradasi verbal, merampas kebebasan untuk pergi keluar, menahan uang dan dukungan keluarga lainnya. Sedangkan lebih dari seperempat wanita mengalami bentuk kekerasan emosional sedang atau parah, dan lebih dari setengahnya sebagian atau seluruhnya dibatasi dalam apa yang akan dilakukan. ${ }^{22}$

\section{Kesimpulan}

1. Gambaran kejadian kekerasan seksual berdasarkan usia paling banyak berada pada kelompok usia 5-14 tahun sebanyak 24 orang (52,2\%)

2. Gambaran kejadian kekerasan seksual berdasarkan tempat pelaporan paling banyak berasal dari Resor Lhokseumawe sebanyak 28 orang $(60,9 \%)$

3. Gambaran kejadian kekerasan seksual berdasarkan jenis kekerasan seksual paling banyak berada pada kelompok tipe penetrasi sebanyak 30 orang $(65,2 \%)$

4. Gambaran kejadian kekerasan seksual berdasarkan hubungan korban dengan pelaku kekerasan seksual paling banyak berada pada kelompok yang berasal dari orang yang tidak dikenal sebanyak 14 orang $(30,4 \%)$

5. Gambaran kejadian korban kekerasan seksual yang juga mengalami kekerasan fisik sebanyak 11 orang $(23,9 \%)$

6. Gambaran kejadian korban kekerasan seksual yang juga mengalami kekerasan verbal sebanyak 18 orang $(39,1 \%)$ 


\section{REFERENSI}

1. Rochaety N. Menegakkan Ham Melalui Perlindungan Hukum Bagi Perempuan Korban Kekerasan Di Indonesia. 2007;7(1):1-24.1. Perbuatan Kekerasan/Pelecehan Seksual Terhadap Perempuan, ST. Lex et Societatis , Vol. I/No.2/Apr-Jun/2013. 2013;I(2):3949

2. Perbuatan Kekerasan/Pelecehan Seksual Terhadap Perempuan, ST. Lex et Societatis , Vol. I/No.2/Apr-Jun/2013. 2013;I(2):39-49

3. Rancangan Undang-Undang Republik Indonesia Tentang Penghapusan Kekerasan Seksual. 2017;1-64.

4. World Health Organization. Global and regional estimates of violence against women: prevalence and health effects of intimate partner violence and non-partner sexual violence. World Health Organization; 2013. p. 1-57.

5. Komnas Perempuan. Catatan Kekerasan Terhadap Perempuan Tahun 2018: Korban Bersuara, Data Bicara, Sahkan Ruu Penghapusan Kekerasan Seksual Sebagai Wujud Komitmen Negara. Jakarta; 2019.

6. World Health Organization. Violence against women [Internet]. World Health Organization; 2017. Available from: https://www.who.int/news-room/factsheets/detail/violence-against-women

7. 15 Bentuk Kekerasan Seksual, Komnas Perempuan,2014 :1-16.

8. Statistik Gender Tematik, Kementerian Pemberdayaan Perempuan dan Pelindungan Anak,2017; 4-123

9. Catatan Kekerasan Terhadap Perempuan Tahun 2017, Komnas Perempuan,13-18

10. Visum Et Repertum Pada Tahap Penyidikan Dalam mengungkap Tindak Pidana Pemerkosaan, Sujadi, 2014: 1-10

11. Keterangan Ahli dan Visum et Repertum dalam Aspek Hukum Acara Pidana, R. Soeparmono, CV Mandar Maju, Bandung, 2016: 25

12. Fallis A. Peranan Visum Et Repertum Dalam Proses Penyidikan Tindak Pidana Kealpaan Menyebabkan Orang Lain Mati (Putusan Pengadilan Negeri Kepanjen No. 607/Pid.B/2014/PN.Kpn). J Chem Inf Model. 2013;53(9):1689-99.

13. Ilmu P, Dalam K, Peradilan S, Abdul O. Visum Et Repertum Dan Proses Peradilan Pidana : :583-93.

14. Peranan Visum Et Repertum Pada Tahap Penyidikan Dalam Mengungkap Tindak Pidana Penganiayaan ; Saviera Chintyara,2018 : 4-19

15. Indrayana, M. T. Profil Kasus Kekerasan Seksual terhadap Perempuan dan Anak yang Diperiksa di Rumah Sakit Bhayangkara Dumai (2009-2013). J Kesehatan Melayu. 2017;1(1):9-13

16. Perez-Fuentes G, Olfson M, Villegas L, Morcillo C, Wang S, Blanco C. Prevalence and correlates of child sexual abuse: a national study. Compr Psychiatry 2013;54(1):16-27.

17. Bourke A, Doherty S, McBride O, Morgan K, McGee H. Female perpetrators of child sesxual abuse: characteristics of the offender and victim. Psychology, crime \& law 2014;20(8):769-80.

18. Bahri, Syaiful., Fajriani. Kajian awal terhadap tingkat pelecehan seksual di Aceh; Jurnal Pencerahan. 9(1), 50-65.

19. Herlianto, B., Adnyana, I.G.A.N.S., Windiani, I.G.A.T., Alit, I.B.P., Soetjiningsih. Karakteristik kekerasan seksual pada anak di RSUP Sanglah Denpasar. Medicina.2019;50(1): 205-209.

20. Biruny, D. M., Rohmah, N., Rifanda, N., et al. Kekerasan Seksual pada Anak: Telaah Relasi Pelaku Korban dan Kerentanan pada Anak. J Psikologi Islam. 2015;12(2): 5-10.

21. Sharon G. Smith et al.,et al. The National Intimate Partner and Sexual Violence Survey: 2015 Data Brief - Updated Release; National Center for Injury Prevention and Control 
Centers for Disease Control and Prevention. 2018; 2-20 
